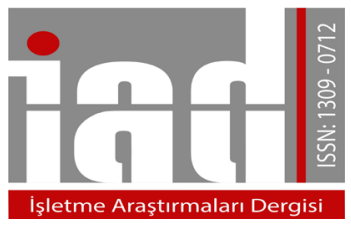

\author{
İşletme Araştırmaları Dergisi \\ Journal of Business Research-Turk \\ 10/4 (2018) 661-680
}

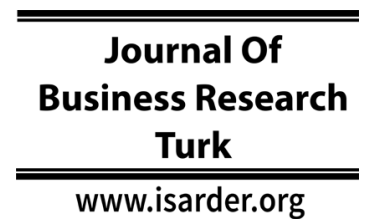

$\underline{\text { Araștırma Makalesi }}$

\title{
Psikolojik Personel Güçlendirmeyi Yöneticinin Güç Kaynaklarıyla Açıklamak: Sağlık Sektöründe Bir Araştırma \\ Explaining the Psychological Empowerment through Managers' Sources of Power: A Research in Health Sector
}

\author{
Alptekin DEVELI \\ Tokat Gaziosmanpaşa Üniversitesi \\ Reşadiye Meslek Yüksekokulu \\ Tokat, Türkiye \\ orcid.org/0000-0001-7232-5603 \\ alptekin.develi@gop.edu.tr
}

\author{
Mustafa Fedai ÇAVUŞ \\ Osmaniye Korkut Ata Üniversitesi \\ İktisadi ve İdari Bilimler Fakültesi \\ Osmaniye, Türkiye \\ orcid.org/0000-0002-2515-5805 \\ mfcavus@osmaniye.edu.tr
}

\author{
Bülent ÖZ \\ Osmaniye Korkut Ata Üniversitesi \\ İktisadi ve İdari Bilimler Fakültesi \\ Osmaniye, Türkiye \\ orcid.org/0000-0001-8756-5386 \\ bulentoz@osmaniye.edu.tr
}

\section{Özet}

$\mathrm{Bu}$ çalışmanın amacı, yöneticinin güç kaynaklarının psikolojik personel güçlendirme algısı üzerindeki açıklayıcılık durumunu belirlemektir. Araştırmanın örneklemi Osmaniye il merkezindeki özel hastanelerde faaliyet gösteren 155 adet çalışandan oluşmaktadır. Nicel araştırma deseni ve ilişkisel tarama modeli kapsamında gerçekleştirilen çalışmada kolayda örnekleme yöntemi ve anket tekniği aracılığıyla veri toplanmıştır. Elde edilen veriler istatistiksel analiz yazılımları aracılığıyla incelenmiştir. Analizler sonucunda uzmanlık gücüne sahip yöneticinin psikolojik personel güçlendirmeyi bir bütün olarak açıklamada negatif yönde katkı yaptığ̀, yasal güçle hareket eden yöneticinin psikolojik personel güçlendirmeye ait anlam boyutunu açıklamada pozitif yönde katkı yaptığı, karizmatik güce sahip yöneticinin psikolojik personel güçlendirmeye ait etki boyutunu açıklamada pozitif yönde katkı yaptığı ve uzmanlık gücüyle hareket eden yöneticinin psikolojik personel güçlendirmeye ait etki boyutunu açıklamada negatif yönde katkı yaptığı sonucuna ulaşılmıştır.

Anahtar Kelimeler: Psikolojik Personel Güçlendirme, Yöneticinin Güç Kaynakları Gönderme Tarihi 7 Eylül 2018; Revizyon Tarihi 2 Aralık 2018; Kabul Tarihi 5 Aralık 2018

\section{Önerilen Atıf/ Suggested Citation:}

Develi, A., Çavuş, M.F., Öz, B. (2018). Psikolojik Personel Güçlendirmeyi Yöneticinin Güç Kaynaklarıyla Açıklamak: Sağlık Sektöründe Bir Araştırma, İ̧sletme Araştırmaları Dergisi, 10 (4), 661680 


\begin{abstract}
The aim of this study is to determine the predictor status of managers' sources of power on the psychological empowerment. The sample of the study is consist of 155 staff working at private hospitals in the city center of Osmaniye, Turkey. The research was conducted within the framework of quantitative research pattern and correlational research design. Data were collected through convenience sampling method-survey technique and investigated via statistical analysis software. As a result of the analyses, it was found that the managers acting with expert power negatively contributed to the explanation of psychological empowerment as a whole, the managers acting with legitimate power positively contributed to the explanation of the meaning the dimension of psychological empowerment, the managers who have referent power positively contributed to the explanation of the impact the dimension of psychological empowerment, and the managers acting with expert power negatively contributed to the explanation of the impact the dimension of psychological empowerment.
\end{abstract}

Keywords: Psychological Empowerment, Managers' Sources of Power

Received 7 September 2018; Received in revised from 2 December 2018; Accepted 5 December 2018

\title{
1. Giriş
}

Örgütsel davranış yazınında iş yaşamındaki en değerli unsurun çalışanlar olduğu genel kabul görmüş bir durumdur. Dolayısıyla çalışanlarla ilgili olan her bir konu önem arz etmektedir. $\mathrm{Bu}$ anlamda modern yönetim kavramları arasında yer alan ve çalışanların kendilerini etkin bir birey olarak algılamaları anlamına gelen (Conger ve Canungo, 1988) psikolojik personel güçlendirmenin iş yaşamında büyük bir önemi vardir.

İlgili yazın incelendiğinde psikolojik personel güçlendirmenin pozitif anlamda pek çok örgütsel çıktı sağladığı anlaşılmaktadır. Psikolojik personel güçlendirmenin; iş doyumunu ve duygusal bağlılığı arttırdığı (Tolay, Sürgevil ve Topoyan, 2012), içsel ve dışsal motivasyonu iyileştirdiği (İhtiyaroğlu, 2017), tükenmişliği azalttığı (Polatcı ve Özçalık, 2013), çalışanların yaratıcılık ve yenilikçilik düzeyine olumlu anlamda katkı sağladığı (Çavuş ve Akgemci, 2008), iş performansını arttırarak işten ayrılma niyetini azalttığı (Kanbur, 2018), örgütsel bağlılık ve örgütsel vatandaşlık davranışını olumlu anlamda açıkladığı (Taşlıyan, Harbalığlu ve Hırlak, 2015) yönündeki bulguları ortaya koyan çalışmalar psikolojik personel güçlendirmenin pozitif örgütsel çıtı sağlayan bir yönetim kavramı olduğu düşüncesine kanıt olarak gösterilebilir.

Belirtildiği üzere örgütlere pek çok fayda sağlayan bir yönetim kavramı olan psikolojik personel güçlendirmenin hangi koşullarla sağlanabileceği konusu, başka bir anlatımla, psikolojik personel güçlendirmenin öncüllerinin neler olduğunun belirlenmesi hususu gerek araştırmacılar gerek yöneticiler tarafından tespit edilmeye çalışılan bir durumdur. Nitekim araştırmanın diğer değişseni olan yöneticinin güç kaynakları konusu bu kapsamda ele alınmıştır.

Bir örgütteki en üst otorite yöneticilerdir. Yöneticiler ve çalışanlar arasındaki ilişkiler ise karşılıklı bağlılık ilişkisi şeklinde gerçekleşmektedir. Dolayısıyla çalışanların yöneticilerine dair algı, tutum ve davranışları yöneticilerin hangi tür güç kaynağıyla davranış sergilediğine göre değişebilecektir. Bu düşüncelerden hareketle 
yöneticilerin kullandıkları güç kaynaklarının psikolojik personel güçlendirmenin olası bir belirleyicisi olacağı öngörülmüştür.

Yazında psikolojik personel güçlendirmenin öncüllerini ve ardıllarını belirlemeye yönelik olarak çok sayıda çalışma bulunmaktadır. Ancak yazında psikolojik personel güçlendirmenin yöneticinin güç kaynakları konusu ile ilişkisini ele alan bir çalışma bulunmamaktadır. $\mathrm{Bu}$ araştırma ile alandaki söz konusu boşluğun doldurulması amaçlanmıştır.

Hem Sosyal Mübadele Teorisi'ne (Blau, 1964) dayanarak hem de ilgili yazından hareketle bu çalışmanın araştırma sorusu; yöneticinin güç kaynaklarının psikolojik personel güçlendirmenin bir açıklayıcısı (yordayıcısı) olup-olmadığıdır.

Çalışmada öncelikle psikolojik personel güçlendirme ve yöneticinin güç kaynakları konuları açıklanmıştır. Ardından bu konular arasındaki ilişki Sosyal Mübadele Teorisi (1964) kapsamında ele alınmıştır. Daha sonra araştırmanın yöntemine dair bilgilere ve uygulama neticesinde elde edilen bulgulara yer verilmiştir. Nihayet, son bölümde çalışmanın sonuçları tartışılarak yöneticilere ve gelecek dönem araştırmalarına önerilerde bulunulmuştur.

\section{Kuramsal Çerçeve}

\subsection{Psikolojik Personel Güçlendirme}

Yazında personel güçlendirme kavramı yapısal personel güçlendirme ve psikolojik personel güçlendirme şeklinde ikiye ayrılarak kavramlaşmıştır. Bu çalışma kapsamında psikolojik personel güçlendirme kavramı ele alınmıştır. Psikolojik personel güçlendirme, çalışanın kendi etkinliğine dair inancına destek olmak, kuvvet vermektir (Conger, 1989). Daha kapsamlı bir ifade ile psikolojik personel güçlendirme; kişilerin beceri ve yetkinlik düzeyleri hakkında kendilerini izledikleri bir süreci ve bu süreçte çalışanların algıladıkları etkinlik düzeylerine katkıda bulunmayı ifade eder (Zimmerman, 1995).

Psikolojik personel güçlendirme algısı, çevresel ve kültürel etkilerden kaynaklanan hem bir süreci hem de bir çıktıyı anlatan bilişsel bir durum olarak tanımlanabilir (Prilleltensky, 2008; Miguel, Ornelas ve Maroco, 2015). Yazındaki ilgili çalışmalarda psikolojik personel güçlendirmenin boyutlarıyla birlikte tanımlanması ve değerlendirilmesi gerektiği ileri sürülmüştür (Spreitzer, 1995). Nitekim söz konusu boyutlar; anlam, yetkinlik, özerklik ve etki olarak ortaya çıkmaktadır.

2.1.1. Anlam: Yerine getirilecek iş ile işgören arasındaki inanç, değer ve davranışların uyumunu ifade eden anlam kavramı, çalışanın yaptığı işin hedefine veya amacına kendi bireysel ölçüleri bakımından biçtiği değer olarak tanımlanabilir (Thomas ve Velthouse, 1990; Brief ve Nord, 1990).

2.1.2. Yetkinlik: Çalışanın sorumluluğu kapsamına giren işlerin gereklerini yerine getirebilmesi için sahip olduğu yetenek ve kapasite düzeyi anlamına gelir (Gist ve Mitchell, 1992).

2.1.3. Özerklik: Bireyin yaptığı iş üzerinde inisiyatif sahibi olduğunu algılamasıdır. Özerklik, yapılan işin başlatılmasına ve düzenlenmesine ilişkin seçme hakkının varlığıdır (Deci, Connell ve Ryan, 1989).

2.1.4. Etki: İşgörenin çalıştığı kurumda alınan stratejik, yönetimsel ve operasyonel düzeydeki kararlar üzerinde etkili olduğunu düşünmesi veya söz konusu karar süreçlerine katkı sağladığını hissetmesidir (Ashfort, 1989). 
Özetle, psikolojik personel güçlendirme; anlam, yetkinlik, özerklik ve etki boyutlarıyla açıklanan motivasyonel bir zihin yapısını ifade etmektedir. Bu dört bilişsel yapı sayesinde çalışanlar daha aktif olmakta ve uyum göstermektedirler (Spreitzer, 1995).

\subsection{Yöneticinin Güç Kaynakları}

Örgütsel davranış yazınında güç kavramı; bir üstün astlarının davranışlarını, tutumlarını, fikirlerini, amaçlarını, ihtiyaçlarını, değerlerini ve tercihlerini kontrol etme veya düzenleme yeteneğini ve yetkisini anlatır (Rahim, 2004). Başka bir ifade ile örgütsel güç, çalışanların davranışlarını belirlemek ve bu davranışların örgütsel amaçlara hizmet etmesini sağlamak için üst yönetim tarafından kullanılan bir aracı ifade eder (Kızanlıklı, Koç ve Kılıçlar, 2016). Örgüt içerisindeki güç olgusu kurumların sosyal motivasyonunu doğrudan etkileme potansiyeline sahip en önemli etkenlerden birisidir (McClelland ve Burnham, 2003). Dolayısıyla, güç olgusu çalışanlar için yüksek düzeyde dikkate alınan bir durum olarak kendisini göstermektedir (Gioia ve Sims, 1983).

Yöneticinin güç kaynakları ile ilgili birçok sınıflandırma bulunmakla birlikte yazında Raven ve arkadaşları (1998) tarafından yapılan sınıflandırmanın genel kabul gördüğü anlaşılmaktadır. Söz konusu sınıflandırmada yöneticinin güç kaynakları altı ayrı türde ele alınmaktadır. Bunlar; zorlayıcı güç, yasal güç, ödüllendirme gücü, karizmatik güç, uzmanlık gücü ve bilgiye dayalı güç şeklindedir (Raven, Schwarzwald ve Koslowsky, 1998).

2.2.1. Zorlayıcı Güç: Astların, üstlerinin talimatlarına veya iş yapma usullerine uygunluk göstermemeleri durumunda onlar tarafindan cezalandırılma ihtimallerinin olduğuna dair algılarını ifade eder (Rahim, 2004). Çalışana fiili güç kullanmak, kıdemini azaltmak, istemediği göreve atamak veya işine son vermek zorlayıcı güce örnek olarak gösterilebilir (Raven, 2008).

2.2.2. Yasal Güç: Çalışanların, üstlerin astlara emir vermesi ve onların davranışlarını kontrol etmesi hususunda hak sahibi olduğuna dair inançlarını ifade eder (Rahim, Kim ve Kim, 1994). Başka bir ifade ile yasal güç, yönetme ve kontrol etme hakkının üstlerde olduğunun kabul edilmesi sebebiyle onların taleplerine itaat etme gerekliliğini anlatır (Raven, 2008).

2.2.3. Ödüllendirme Gücü: Astların, üstlerinin örgüt içerisinde arzulanan davranışların gerçekleştiğini görmesi halinde onlara ödül vereceğine dair algılarını ifade eder (Rahim, 2004). Ücret zammı sağlama, terfi ettirme, daha iyi bir iş verme ve övgüde bulunma ödüllendirme gücüne örnek olarak verilebilir (Koçel, 2013).

2.2.4. Karizmatik Güç: Karizmatik güç direkt olarak üstlerin kişiliğiyle ilgilidir. Üstün sahip olduğu kişiliğin astlara ilham verebilmesi, onların arzu ve isteklerini dile getirmesi ve neticede onlar tarafindan örnek alınması bu güç kaynağının temellerini oluşturur (Shetty, 1978).

2.2.5. Uzmanlık Gücü: Astların, üstlerinin mevcut koşullar altında yapılacak en iyi şeyin ne olduğuyla ilgili bilgiye ve gerekli bakış açısına sahip olduğuna dair inançlarıdır (Raven, 2008). Başka bir deyişle uzmanlık gücü, çalışılan sektördeki üst düzey personelin iş yaptığı alanla ilgili değerli yeteneklere, tecrübelere ve uzmanlığa vakıf olduğuna dair algılardır (Rahim vd., 1994).

2.2.6. Bilgiye Dayalı Güç: Bilgiye dayalı güç, üstlerin başkaları tarafından edinilmesi zor olan bilgilere sahip olmalarından dolayı inandırıcılık ve akılcı ikna 
kapasitelerinin etkili olmasını ifade eder (Meydan, 2010). Burada üst astına işlerin nasıl yapılması gerektiğini detaylarıyla ve sebepleriyle birlikte açıklar ve neticede astın üzerinde verilen talimatlara itaat etmesi gerektiğine dair bir algı oluşur (Raven, 2008).

\subsection{Psikolojik Personel Güçlendirme ve Yöneticinin Güç Kaynakları Arasındaki İlişki}

Psikolojik personel güçlendirme ve yöneticinin güç kaynakları arasındaki ilişki Sosyal Mübadele Teorisi (Blau, 1964) ile açıklanabilir. Sosyal Mübadele Teorisi karşılıklı gerçekleşen ilişkilerin açıklanmasında kullanılan teorilerin başında gelmektedir. Bu teoriye göre karşılıklı insan ilişkileri sadece ekonomik anlamda değil aynı zamanda psikolojik ve sosyolojik anlamda bir değiş tokuş ilişkisine benzetilmiştir (Cropanzano ve Mitchell, 2005). Teoriye göre kişilerarası ilişkiler karşılıklı olarak birbirine bağımlı sosyal yükümlülükler üreten faaliyetler dizisi olarak tanımlanmaktadır (Karagonlar, Öztürk ve Özmen, 2015).

Sosyal Mübadele Teorisi'nin iş hayatındaki yerine bakıldığında bu teorinin işveren ve çalışan arasındaki ilişkileri açıkladığını belirten çok sayıda çalışma olduğu söylenebilir (Cropanzano ve Mitchell, 2005; Ateş, 2017; Yıldız ve Y1ldız; 2015). Buna göre işveren, çalışanlarına karşı olumlu tutum ve davranışlar gösterdiğinde çalışanlar da hem işverenlerine hem de örgütlerine karşı olumlu tutum ve davranışlar göstereceklerdir (Rhoades, Eisenberger ve Armeli, 2001). Benzer şekilde işvereni tarafindan olumsuz tutum ve davranışlara maruz kalan çalışan ise aynı şekilde karşılık verme yöneliminde olacaktır. Bu bağlamda ele alındığında teorinin psikolojik personel güçlendirme ve yöneticinin güç kaynakları arasındaki ilişkileri açıklayan güçlü bir kuram olduğu düşünülmektedir. Çünkü yöneticiler ve çalışanlar arasındaki ilişkiler tıpkı teoride ifade edildiği gibi karşılıklılık ilkesi gereğince gerçekleşen ilişkilerdir. İlaveten, teoride belirtilen insan ilişkilerinin ekonomik, sosyal ve psikolojik anlamda bir değiş tokuş ilişkisine benzetilmesi de yine psikolojik personel güçlendirme ve yöneticinin güç kaynakları arasındaki ilişkilere işaret etmektedir. Çünkü bir çalışan yöneticisinin gösterdiği tutum ve davranışlara göre karşı tutum ve davranışlar gösterme eğiliminde olacaktır.

Yazında Sosyal Mübadele Teorisi (Blau, 1964) ile açıklanan çalışmalar genellikle alg1-tutum-davranış üçlüsü kapsamına giren çalışmalardır. Başka bir anlatımla, Sosyal Mübadele Teorisi daha çok algıların tutumlara, tutumların da davranışlara dönüştüğü türde konuları içeren çalışmaları açıklamak için kullanılmıştır. Ancak çalışanların hem psikolojik personel güçlendirme düzeyleri hem de yöneticilerinin hangi tür güç kaynağını kullandıklarına dair izlenimleri algı düzeyinde gerçekleşen durumlardır. Bu doğrultuda bakıldığında psikolojik personel güçlendirme ve yöneticinin güç kaynakları arasındaki ilişkileri Sosyal Mübadele Teorisi ile açıklamak yetersiz gibi görünse de yazında algıların algıları veya tutumların tutumları etkilediği durumların da ilgili teori kapsamında açıklanabileceği belirtilmiştir (Barbuto ve Hayden, 2011; Yıldız, 2016).

Netice itibariyle, hem Sosyal Mübadele Teorisi'nin (Blau, 1964) yönergelerine dayanarak hem de ilgili yazından hareketle yöneticinin güç kaynaklarının psikolojik personel güçlendirmenin bir açıklayıcısı (yordayıcısı) olacağı düşünülmüştür. Başka bir deyişle, yöneticinin güç kaynaklarının psikolojik personel güçlendirmenin bir öncülü (belirleyicisi) olacağ 1 öngörülmüştür.

\section{Araştırmanın Yöntemi}

Nicel araştırma deseni ve ilişkisel tarama modeli kapsamında gerçekleştirilen çalışmada kolayda örnekleme yöntemi ve anket tekniği kullanılmıştır. Bu doğrultuda 
Osmaniye il merkezindeki özel hastane personeli arasından 169 kişiye anket formu ulaştırılmıştır. Anketler yüz yüze görüşme yoluyla ve katılımcılara araştırmanın amacını ve önemini ifade etmek suretiyle uygulanmıştır. Öncelikle elde edilen veriler analizler için hazır hale getirilmiştir. Bu amaçla kayıp değer, uç değer ve normal dağılım analizi yapılmıştır. Ayrıca elde edilen verilerde ortak yöntem sapması probleminin olupolmadığ incelenmiştir. Sonrasında araştırmada kullanılan ve Türkiye'deki geçerlilikleri ispatlanmış olan ölçeklerin içsel tutarlılıklarını belirlemek amacıyla güvenilirlik düzeyleri hesaplanmıştır. Tanımlayıcı istatistik analizi aracılığıyla katılımcıların araştırma değişkenlerine ilişkin düzeyleri ölçülmüş ve yöneticinin güç kaynakları ve psikolojik personel güçlendirme arasındaki ilişkiler korelasyon analizi aracılığıyla incelenmiştir. Son olarak yöneticinin güç kaynaklarının psikolojik personel güçlendirme algısı üzerindeki açıklayıcılık (yordayıcılık) durumunu belirlemek üzere regresyon analizi kullanılmıştır.

\subsection{Araştırmanın Amacı ve Önemi}

$\mathrm{Bu}$ çalışmanın temel amacı yöneticinin güç kaynaklarının psikolojik personel güçlendirme algısı üzerindeki açıklayıcılık (yordayıcılık) durumunu belirlemektir. Yazında pek çok konunun çalışanların psikolojik personel güçlendirme algısı ile ilişkisi araştırılmış durumdadır. Ancak yöneticin güç kaynakları konusunun psikolojik personel güçlendirme konusu ile ilişkisini inceleyen bir çalışma bulunmamaktadır. Diğer yandan yazında örgütlerdeki güç konusunun gerek araştırmacılar gerek yöneticiler tarafından ihmal edilen bir konu olduğu belirtilmiştir (Bayrak, 2001; Koçel, 2013). Dolayısıyla bu çalışmanın bilimsel birikime ve iş yaşamına sağlayacağı katkı bakımından özgün bir değeri bulunmaktadır.

\subsection{Araştırmanın Modeli}

Zorlayıc1 güç, yasal güç, ödüllendirme gücü, karizmatik güç, uzmanlık gücü ve bilgiye dayalı güç boyutlarından oluşan yöneticinin güç kaynaklarının; bir bütün olarak psikolojik personel güçlendirme ve psikolojik personel güçlendirmenin boyutları olan anlam, yetkinlik, özerklik ve etki üzerindeki açıklayıcılık durumunu belirlemek üzere tasarlanan bu çalışmanın model olarak gösterimi aşağıdaki gibidir:

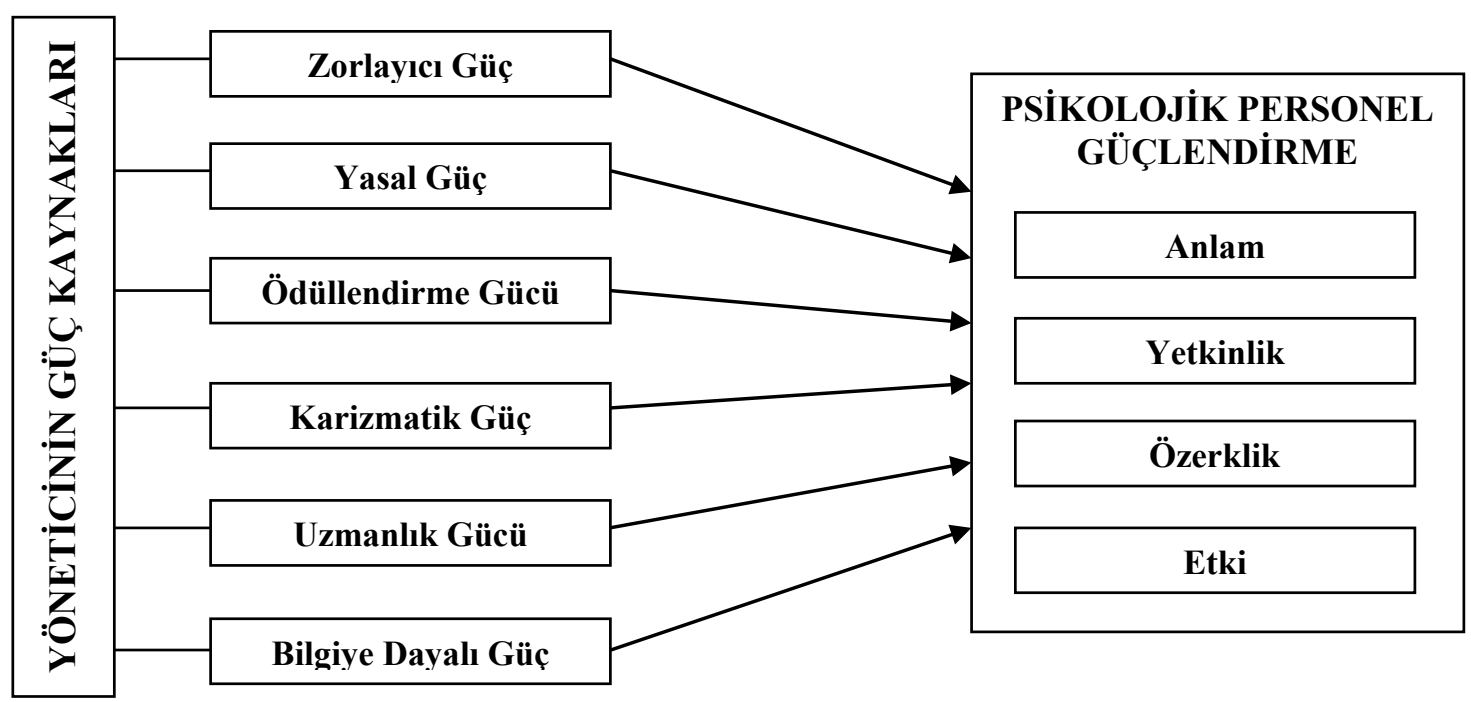

Şekil 1. Araştırma Modeli 


\subsection{Kayıp Değer, Uç Değer ve Normal Dağılım Analizi}

Katılımcılardan elde edilen veriler öncelikle analizlere hazır hale getirilmiş̧tir. $\mathrm{Bu}$ amaçla ilk olarak kayıp değer analizi (missing value analysis) yapılmıştır. Yapılan kayıp değer analizi sonucunda 14 adet anket formu eksik cevap hatası sebebiyle gözlem dış1 bırakılmıştır. Sonrasında uç değer (outliers) analizi yapılmıştır. Mahalanobis Uzaklığı Yöntemi kullanılarak yapılan uç değer analizinde $\mathrm{p}<.01$ anlamlılık düzeyinde deneklerin merkezine uzak olan bir veri bulunmaması sebebiyle veri setinde uç değer olmadığı tespit edilmiştir (Mahalanobis, 1936). Sorunlu anket formları çıkarıldıktan sonra veri setindeki nihai katılımcı sayısı $155^{\prime}$ tir $(\mathrm{n}=155)$. Son olarak araştırmada kullanılacak analiz türlerinin (parametrik veya non-parametrik) belirlenebilmesi için elde edilen verilerin normal dağılım gösterip-göstermediği kontrol edilmiştir. Bunu belirlemek için ise her bir ifadenin çarpıklık-basıklık (skewness-kurtosis) değerlerine bakılmıştır. Bulgulara göre en büyük çarpıklık değeri: -2.23 , en büyük basıklık değeri: 6.69 'dur. Çarpıklık değerleri \pm 3 ve basıklık değerleri \pm 10 eşik değerlerinin içerisinde olduğu için verilerin normal dağılım gösterdiği sonucuna ulaşılmıştır (Kline, 2011). Bu sebeple araştırmada parametrik analizler kullanılmıştır.

\subsection{Ortak Yöntem Sapması Testi}

Nicel araştırmalarda elde edilen verilerin incelenmesinden önce kontrol edilmesi gereken bir diğer husus ortak yöntem sapması (common method variance) problemidir. Ortak yöntem sapması; araştırmalarda öz değerlendirme yönteminin kullanılması, birden çok ölçeğin aynı anket formu üzerinde yer alması, anket formunda kullanılan birden çok ölçeğin aynı yapıdaki ölçek tipleri üzerinden cevaplandırılması (Likert ölçeği, semantik farklılıklar ölçeği vb.), tüm ölçeklerin aynı zamanlarda ve aynı bölgelerdeki katılımcılar tarafından değerlendirilmesi, ölçek sorularının karakteristik özellikleri, anket formunun uzunluğu, katılımcıların değișen duygu durumları ve sosyal arzulanırlık eğiliminde olmaları sebebiyle sorulara yanlı cevap vermeleri sebepleriyle oluşabilecek bir problemdir. Ortak yöntem sapması, gözlenen değişkenler arasındaki ilişkilerde ölçme hatalarına sebep olan ve dolayısıyla kontrol edilmesi gereken bir problemdir. Harman'ın tek faktör testi, ortak yöntem sapması problemini belirlemek için kullanılan yöntemlerden bir tanesidir. Bu test yapılırken araştırmada kullanılan tüm ifadeler döngüsüz faktör analizi aracilığılla analize tabi tutulur. Test neticesinde ortak yöntem sapması probleminden bahsedebilmek için ya tek bir faktörün elde edilmesi ya da tek ve genel faktörün varyansın önemli bir bölümünü açıklaması gereklidir (Podsakoff ve Organ, 1986; Podsakoff, MacKenzie, Lee ve Podsakoff, 2003). Bu doğrultuda anket formunda kullanılan 10 değişkene ait toplamda 45 ifade döngüsüz faktör analizi aracılığıyla analize tabi tutulmuştur. Bulgulara göre ifadeler tek boyutta toplanmayarak 10 alt kırılımdan oluşan çok boyutlu bir yapı sergilemiş̧tir. Ayrıca tek ve genel bir faktör elde edebilmek için açıklayıcı faktör analizinde faktör sayısı 1'e sabitlendiğinde oluşan tek faktörün toplam varyansın çoğunluğunu değil, \%24'üne tekabül eden düşük bir kısmını açıkladığı görülmüştür. Buna göre elde edilen verilerde ortak yöntem sapması probleminin olmadığı bulgulanmıştır.

\subsection{Araştırmanın Evreni ve Örneklemi}

Araştırmanın evreni Osmaniye il merkezindeki özel hastane çalışanlarıdır. Osmaniye il merkezinde araştırmanın yapıldığı dönemde (Şubat, 2017) hizmet veren dört adet özel hastane bulunmaktadır. Bu hastanelerin her birindeki çalışanlardan kolayda örnekleme yöntemi aracılığıyla veri toplanmıştır. Katılımcıların demografik özellikleri Tablo 1'de görülmektedir $(\mathrm{n}=155)$. 
Demografik özelliklere bakıldığında 155 kişiden oluşan katılımcıların \%70.3'ünün kadın (109 kişi), \%29.7'sinin erkek (46 kişi) olduğu görülmektedir. Katılımcıların \%45.2'si (70 kişi) 18-25 yaş aralığı ile en büyük payı oluşturmaktadır. Sonrasında \%30.3'lük (47 kişi) bir pay ile 26-35 yaş arasındaki katılımcılar yer almaktadır. \%17.4'lük (27 kişi) dilim 36-45 yaş arasındaki katılımcıları temsil ederken, en küçük payı \%7.1 (11 kişi) oranı ile 46 üstü yaş grubu teşkil etmektedir. Katılımcıların \%43.2'si (67 kişi) lise düzeyinde eğitimlidir. Bu oranı \%25.2 (39 kişi) ile ön lisans düzeyinde eğitimliler, \%19.4 (30 kişi) ile lisans düzeyinde eğitimliler, \%6.5 (10 kişi) ile yüksek lisans düzeyinde eğitimliler ve \%5.8 (9 kişi) ile doktora düzeyinde eğitimli olanlar takip etmektedir. Mevcut işyerinde çalışma süresi anlamında çoğunluğun 2 yıldan az çalışma tecrübesine sahip çalışanlardan oluştuğu (\%51.6 / 80 kişi) ve iş hayatındaki toplam çalışma süresi anlamında ise çoğunluğun 2 yıldan az ve 28 yıl aralığında çalışma tecrübesine sahip çalışanlardan oluştuğu (\%33.5 / 52 kişi) görülmektedir.

Tablo 1. Araştırmaya Katılanların Demografik Özellikleri

\begin{tabular}{|c|c|c|c|}
\hline \multicolumn{2}{|c|}{ Demografik Faktörler } & \multirow{2}{*}{$\begin{array}{c}\text { Frekans } \\
46\end{array}$} & \multirow{2}{*}{$\frac{\text { Yüzde }}{29.7}$} \\
\hline & Erkek & & \\
\hline Cinsiyet & Kadın & 109 & 70.3 \\
\hline \multirow{4}{*}{ Yaş Aralığ } & $18-25$ & 70 & 45.2 \\
\hline & $26-35$ & 47 & 30.3 \\
\hline & $36-45$ & 27 & 17.4 \\
\hline & $46+$ & 11 & 7.1 \\
\hline \multirow{5}{*}{ Eğitim Düzeyi } & Lise & 67 & 43.2 \\
\hline & Ön Lisans & 39 & 25.2 \\
\hline & Lisans & 30 & 19.4 \\
\hline & Yüksek Lisans & 10 & 6.5 \\
\hline & Doktora & 9 & 5.8 \\
\hline \multirow{4}{*}{ Meslek Grubu } & Doktor & 24 & 15.5 \\
\hline & Hemşire & 76 & 49.0 \\
\hline & Sağlık Personeli & 22 & 14.2 \\
\hline & İdari Personel & 33 & 21.3 \\
\hline \multirow{3}{*}{$\begin{array}{l}\text { Mevcut İşyerinde } \\
\text { Çalışma Süresi }\end{array}$} & 2 yildan az & 80 & 51.6 \\
\hline & $2-8$ yil & 57 & 36.8 \\
\hline & $9-14$ y1l & 18 & 11.6 \\
\hline \multirow{5}{*}{$\begin{array}{l}\text { Toplam Çalışma } \\
\text { Süresi }\end{array}$} & 2 yildan az & 52 & 33.5 \\
\hline & $2-8$ y1l & 52 & 33.5 \\
\hline & $9-14$ y1l & 41 & 26.5 \\
\hline & $15-20 \mathrm{y} 11$ & 3 & 1.9 \\
\hline & 21 yıldan fazla & 7 & 4.5 \\
\hline
\end{tabular}

Not: $\mathrm{n}=155$

\section{6. Ölçme Araçları}

Araştırma kapsamında yöneticinin güç kaynakları algısını ölçmek için Raven ve arkadaşları (1998) tarafından geliştirilen ve Türkiye örneklemindeki geçerlilik çalışması Meydan (2010) tarafından yapılan ölçek kullanılmıştır. Ölçek 6 boyut ve 33 ifadeden oluşmaktadır. Ölçeğin boyutları; zorlayıcı güç (6 ifade), yasal güç (12 ifade), ödüllendirme gücü (6 ifade), karizmatik güç (3 ifade), uzmanlık gücü (3 ifade) ve bilgiye dayalı güç (3 ifade) şeklindedir.

Psikolojik personel güçlendirme algısını ölçmek için ise Spreitzer (1995) tarafindan geliştirilen ve Türkiye örneklemindeki geçerlilik çalışması Sürgevil ve 
arkadaşları (2013) tarafindan yapılan ölçekten faydalanılmıştır. Ölçek dört boyut ve 12 ifadeden oluşmaktadır. Ölçeğin boyutları; anlam ( 3 ifade), yetkinlik ( 3 ifade), özerklik ( 3 ifade) ve etki ( 3 ifade) şeklindedir.

Tüm ölçeklerdeki ifadeler Beşli Likert ölçeği ile yapılandırılmıştır $(1=$ Kesinlikle Katılmıyorum; 5 = Kesinlikle Katılıyorum). Anketin giriş bölümünde, çalışanların demografik özelliklerini belirlemeye yönelik olarak cinsiyet, yaş, eğitim düzeyi, meslek grubu, mevcut kurumda çalışma süresi ve iş hayatındaki toplam çalışma süresini ölçen sorular yer almaktadır. Anket formu ile elde edilen veriler istatistiksel analiz yazılımları aracılığıyla analiz edilmiştir.

\section{Bulgular}

\subsection{Tanımlayıcı İstatistik ve Güvenilirlik Analizi}

Araştırma kapsamında kullanılan her iki ölçeğe ait ifadelerin ait oldukları boyutlara göre faktör yapıları oluşturulmuştur. Yöneticinin güç kaynakları ölçeğinin faktör yapısının orijinal ölçekteki aynı ifadelerle Türkiye'de de geçerli olduğu (Meydan, 2010) ve psikolojik personel güçlendirme ölçeğinin faktör yapısının yine orijinal ölçekteki aynı ifadelerle Türkiye'de geçerli olduğu (Sürgevil, Tolay ve Topoyan, 2013) ispatlandığı için ifadelerin ait oldukları boyutlara göre birleştirilmeleri sağlanmıştır. Bununla birlikte, ölçme araçlarının ve boyutlarının içsel tutarlılıklarını belirlemek amacıyla Cronbach's alfa $(\alpha)$ yöntemiyle güvenilirlik analizi yapılmıştır (Cronbach, 1951). Yapılan güvenilirlik analizinde bilgiye dayalı güç türünün güvenilirlik düzeyi $(\alpha$ $=.31$ ) önemli ölçüde düşük olduğu için sadece bu boyut araştırma modelinden çıkarılmıştır. Bununla birlikte, araştırmada incelenen konular açısından örneklemin yapısını ortaya çıkarabilmek amacıyla tanımlayıcı istatistik analizi yapılmıştır. İlgili sonuçlar Tablo 2'de görülmektedir.

Tanımlayıcı istatistik analizinin sonucundaki ortalama değerleri $(\overline{\mathbf{x}})$ dikkate alındığında özel hastane çalışanlarının hem yöneticilerinin kullandıkları güç kaynaklarını algıladıkları $(\overline{\mathbf{x}}=3.66)$ hem de psikolojik personel güçlendirme algısına sahip oldukları $(\overline{\mathbf{x}}=4.11)$ görülmektedir. Çalışanların yöneticilerinin hangi tür güç kaynağı kullandıklarına dair en yüksek algı düzeyleri sırasıyla; yasal güç $(\overline{\mathbf{x}}=3.71)$, ödüllendirme gücü $(\overline{\mathbf{x}}=3.66)$, uzmanlık gücü $(\overline{\mathbf{x}}=3.64)$, karizmatik güç $(\overline{\mathbf{x}}=3.63)$ ve zorlayıcı güç $(\overline{\mathbf{x}}=3.58)$ şeklindedir. Çalışanların psikolojik personel güçlendirmeyi hangi boyutuyla daha yüksek algıladıkları sirasıyla; anlam $(\overline{\mathbf{x}}=4.43)$, yetkinlik $(\overline{\mathbf{x}}=$ 4.33), etki $(\overline{\mathbf{x}}=3.89)$ ve özerklik $(\overline{\mathbf{x}}=3.76)$ şeklindedir.

Tablo 2. Tanımlayıcı İstatistikler ve Güvenilirlik Düzeyleri

\begin{tabular}{lcccc}
\hline Ölçme Araçları ve Boyutları & $\overline{\mathbf{x}}$ & $\boldsymbol{s}$ & İfade Sayısı & $\boldsymbol{\alpha}$ \\
\hline Yöneticinin güç kaynakları & 3.66 & .64 & 33 & .92 \\
\hline Zorlayıcı güç & 3.58 & .84 & 6 & .76 \\
\hline Yasal güç & 3.71 & .61 & 12 & .79 \\
\hline Ödüllendirme gücü & 3.66 & .77 & 6 & .75 \\
\hline Karizmatik güç & 3.63 & .85 & 3 & .62 \\
\hline Uzmanlık gücü & 3.64 & .97 & 3 & .73 \\
\hline Psikolojik personel güçlendirme & 4.11 & .64 & 12 & .88 \\
\hline Anlam & 4.43 & .68 & 3 & .78 \\
\hline Yetkinlik & 4.33 & .71 & 3 & .80 \\
\hline Özerklik & 3.76 & 1.04 & 3 & .85 \\
\hline Etki & 3.89 & .86 & 3 & .78 \\
\hline
\end{tabular}

Not: $\mathrm{n}=155, \overline{\mathrm{x}}$ : Örneklem ortalaması, $s$ : Örneklem standart sapması, $\alpha$ : Cronbach's alfa katsayıs1 
Güvenilirlik analizi sonuçları incelendiğinde yöneticinin güç kaynakları $(\alpha=.92)$ ve psikolojik personel güçlendirme $(\alpha=.88)$ ölçeklerine ait genel alfa katsayısı düzeyi literatürde genel kabul görmüş olan $\alpha \geq .70$ eşik değerinin üzerindedir (Nunnaly, 1978). İlgili ölçeklerin boyutlarına bakıldığında ise sadece yöneticinin güç kaynaklarına ait karizmatik güç $(\alpha=.62)$ boyutunun alfa katsayısı $\alpha \geq .70$ eşik değerinin altındadır. Ancak karizmatik güç boyutunun Türkiye örneklemindeki geçerliliğini yapan çalışmada da alfa katsayısı, $\alpha \geq .70$ eşik değerinin altında, $\alpha=.68$ olarak elde edilmiştir (Meydan, 2010). Nitekim literatürde .50'nin üzerinde olan alfa katsayılarının da bir içsel tutarlılık göstergesi olduğu öne sürülmüştür (Bowling, 2002). Ayrıca .60 ve üzeri alfa katsayılarının güvenilir düzeyde olduğunu ifade eden çalışmalar da bulunmaktadır (Karagöz, 2016). Bu değerlendirmelerden hareketle, tüm değişkenlere ait Cronbach's Alfa değerleri ölçeklerin içsel tutarlılıklarının güvenilir düzeyde var olduğunu göstermektedir.

\subsection{Pearson Korelasyon Analizi}

Araştırma modeli kapsamında; zorlayıcı güç, yasal güç, ödüllendirme gücü, karizmatik güç ve uzmanlık gücü değişkenleri ile bir bütün olarak psikolojik personel güçlendirme ve psikolojik personel güçlendirmenin boyutları olan anlam, yetkinlik, özerklik ve etki değişkenlerinin birlikte değişme yönlerini ve şiddetlerini belirlemek üzere Pearson korelasyon analizi yapılmıştır. Sonuçlar Tablo 3'de görülmektedir.

Tablo 3. Pearson Korelasyon Analizi Sonuçları

\begin{tabular}{|c|c|c|c|c|c|c|c|c|c|c|}
\hline Değişkenler & 1 & 2 & 3 & 4 & 5 & 6 & 7 & 8 & 9 & 10 \\
\hline 1 Zorlayıcı güç & 1 & & & & & & & & & \\
\hline 2 Yasal güç & $.69 * *$ & 1 & & & & & & & & \\
\hline 3 Ödüllendirme gücü & $.56 * *$ & $.75^{* *}$ & 1 & & & & & & & \\
\hline 4 Karizmatik güç & $.54 * *$ & $.69 * *$ & $.67 * *$ & 1 & & & & & & \\
\hline 5 Uzmanlık gücü & $.47 * *$ & $.65 * *$ & $.61 * *$ & $.63 * *$ & 1 & & & & & \\
\hline $\begin{array}{ll}6 & \text { Psk. p. güçlendirme }\end{array}$ & $.20 * *$ & $.22 * *$ & $.26 * *$ & $.24 * *$ & .07 & 1 & & & & \\
\hline 7 Anlam & $.19 *$ & $.33 * *$ & $.32 * *$ & $.23 * *$ & .14 & $.80 * *$ & 1 & & & \\
\hline 8 Yetkinlik & $.21 * *$ & $.17 *$ & .15 & $.16^{*}$ & .06 & $.79 * *$ & $.75 * *$ & 1 & & \\
\hline 9 Özerklik & .11 & .05 & .14 & .12 & .00 & $.73 * *$ & $.33 * *$ & $.32 * *$ & 1 & \\
\hline 10 Etki & .15 & $.21 * *$ & $.24 * *$ & $.24 * *$ & .04 & $.81 * *$ & $.57 * *$ & $.54 * *$ & $.44 * *$ & 1 \\
\hline
\end{tabular}

* işareti $\mathrm{p}<.05$ anlamlılık düzeyini, ** işareti $\mathrm{p}<.01$ anlamlılık düzeyini göstermektedir.

Pearson korelasyon analizi sonuçlarına göre yöneticinin güç kaynakları ile bir bütün olarak psikolojik personel güçlendirme ve boyutları arasında istatistiksel olarak anlamlı ilişki bulunan ikili değişkenler şu şekildedir: zorlayıcı güç ve psikolojik personel güçlendirme $(\mathrm{r}=.20, \mathrm{p}<.01)$, zorlayıcı güç ve anlam boyutu $(\mathrm{r}=.19, \mathrm{p}<.05)$, zorlayıcı güç ve yetkinlik boyutu $(\mathrm{r}=.21, \mathrm{p}<.01)$, yasal güç ve psikolojik personel güçlendirme $(\mathrm{r}=.22, \mathrm{p}<.01)$, yasal güç ve anlam boyutu $(\mathrm{r}=.33, \mathrm{p}<.01)$, yasal güç ve yetkinlik boyutu $(\mathrm{r}=.17, \mathrm{p}<.05)$, yasal güç ve etki boyutu $(\mathrm{r}=.21, \mathrm{p}<.01)$, ödüllendirme gücü ve psikolojik personel güçlendirme $(\mathrm{r}=.26, \mathrm{p}<.01)$, ödüllendirme gücü ve anlam boyutu $(\mathrm{r}=.32, \mathrm{p}<.01)$, ödüllendirme gücü ve etki boyutu $(\mathrm{r}=.24, \mathrm{p}<$ $.01)$, karizmatik güç ve psikolojik personel güçlendirme $(r=.24, p<.01)$, karizmatik güç ve anlam boyutu $(\mathrm{r}=.23, \mathrm{p}<.01)$, karizmatik güç ve yetkinlik boyutu $(\mathrm{r}=.16, \mathrm{p}<$ $.05)$, karizmatik güç ve etki boyutu $(\mathrm{r}=.24, \mathrm{p}<.01)$. Yöneticinin güç kaynakları ile bir bütün olarak psikolojik personel güçlendirme ve boyutları arasındaki diğer ikili ilişkiler istatistiksel olarak anlamsızdır $(\mathrm{p}>.05)$. 


\section{3. Çoklu Doğrusal Regresyon Analizi}

Araştırma modelinin bağımsız değişkenleri olan zorlayıcı güç, yasal güç, ödüllendirme gücü, karizmatik güç ve uzmanlık gücünün bağımlı değişkenler olan psikolojik personel güçlendirme, anlam, yetkinlik, özerklik ve etki üzerindeki açıklayıcılık (yordayıcılık) durumlarını belirlemek amacıyla çoklu doğrusal regresyon analizi yapılmıştır. Sonuçlar Tablo 4'te görülmektedir.

Tablo 4. Çoklu Doğrusal Regresyon Analizi Sonuçları

\begin{tabular}{|c|c|c|c|c|c|c|c|c|}
\hline & $\begin{array}{c}\text { Bağımsız } \\
\text { Değișkenler }^{\mathrm{a}}\end{array}$ & $\begin{array}{l}\text { Bağımlı } \\
\text { Değişken }\end{array}$ & $\boldsymbol{\beta}$ & $\mathbf{r}$ & $\mathbf{R}^{2}$ & $\mathbf{F}$ & $\mathbf{p}$ & D-W \\
\hline & Zorlayıcı güç & \multirow{5}{*}{$\begin{array}{c}\text { Psikolojik } \\
\text { personel } \\
\text { güçlendirme }\end{array}$} & .06 & \multirow{5}{*}{.33} & \multirow{5}{*}{.11} & \multirow{5}{*}{3.713} & \multirow{5}{*}{.003} & \multirow{5}{*}{1.74} \\
\hline & Yasal güç & & .06 & & & & & \\
\hline 1 & Ödüllendirme gücü & & .21 & & & & & \\
\hline & Karizmatik güç & & .17 & & & & & \\
\hline & Uzmanlık gücü & & $-.24 *$ & & & & & \\
\hline \multirow{5}{*}{2} & Zorlayıc1 güç & \multirow{5}{*}{ Anlam } & -.08 & \multirow{5}{*}{.38} & \multirow{5}{*}{.14} & \multirow{5}{*}{5.047} & \multirow{5}{*}{.000} & \multirow{5}{*}{1.81} \\
\hline & Yasal güç & & $.33 *$ & & & & & \\
\hline & Ödüllendirme gücü & & .21 & & & & & \\
\hline & Karizmatik güç & & .02 & & & & & \\
\hline & Uzmanlık gücü & & -.19 & & & & & \\
\hline \multirow{5}{*}{3} & Zorlayıcı güç & \multirow{5}{*}{ Yetkinlik } & .16 & \multirow{5}{*}{.24} & \multirow{5}{*}{.05} & \multirow{5}{*}{1.821} & \multirow{5}{*}{.112} & \multirow{5}{*}{1.85} \\
\hline & Yasal güç & & .06 & & & & & \\
\hline & Ödüllendirme gücü & & .02 & & & & & \\
\hline & Karizmatik güç & & .10 & & & & & \\
\hline & Uzmanlık gücü & & -.13 & & & & & \\
\hline \multirow{5}{*}{4} & Zorlayıcı güç & \multirow{5}{*}{ Özerklik } & .12 & \multirow{5}{*}{.23} & \multirow{5}{*}{.05} & \multirow{5}{*}{1.680} & \multirow{5}{*}{.143} & \multirow{5}{*}{1.60} \\
\hline & Yasal güç & & -.19 & & & & & \\
\hline & Ödüllendirme gücü & & .21 & & & & & \\
\hline & Karizmatik güç & & .15 & & & & & \\
\hline & Uzmanlık gücü & & -.15 & & & & & \\
\hline \multirow{5}{*}{5} & Zorlayıcı güç & \multirow{5}{*}{ Etki } & -.01 & \multirow{5}{*}{.33} & \multirow{5}{*}{.11} & \multirow{5}{*}{3.733} & & \\
\hline & Yasal güç & & .10 & & & & & \\
\hline & Ödüllendirme gücü & & .19 & & & & .003 & 1.85 \\
\hline & Karizmatik güç & & $.23 *$ & & & & & \\
\hline & Uzmanlık gücü & & $-.28 *$ & & & & & \\
\hline
\end{tabular}

Not: $\beta$ : Standardize edilmiş Beta katsayısı, $\mathrm{R}^{2}$ : Belirlilik katsayısı, F: F testi istatistiği, $\mathrm{p}$ : İstatistiksel anlamlılık düzeyi, D-W: Durbin-Watson değeri.

a Varyans büyütme faktör değerleri: $\mathrm{ZG}=1.94, \mathrm{YG}=3.53, \mathrm{O} G=2.64, \mathrm{KG}=2.34, \mathrm{UG}=2.03$

$*$ işareti $\mathrm{p}<.05$ anlamlılık düzeyini, ** işareti $\mathrm{p}<.01$ anlamlılık düzeyini göstermektedir.

Öncelikle kurulan modellerde doğru sonuçlara ulaşabilmek için ölçme hataları ve hatalar arasındaki ilişkilere yönelik regresyon varsayımlarından sapmalar olup olmadığ1 kontrol edilmiştir. Buna göre, tüm değişkenlerin Durbin-Watson değeri (D-W) 2'den küçük olduğu için hata terimlerinin arasında ilişki olmadığı yani otokorelasyon probleminin olmadığı görülmüştür (Durbin ve Watson, 1971). Bununla birlikte, bağımsız değişkenlerin varyans büyütme faktör değerleri (VIF) 5 'ten küçük olduğu için çoklu doğrusallık probleminin olmadığı tespit edilmiştir (O’Brien, 2007).

Birinci regresyon modelinde bağımsız değişkenler olan zorlayıcı güç, yasal güç, ödüllendirme gücü, karizmatik güç ve uzmanlık gücü ile bağımlı değişken olan psikolojik personel güçlendirme arasında yapılan çoklu doğrusal regresyon analizinin sonuçları görülmektedir. $\mathrm{F}$ değeri $\% 1$ anlamlılık düzeyinde istatistiksel olarak anlamlıdır $\left[\mathrm{F}_{(5,149)}=3.713, \mathrm{p}<.01\right]$. Yani bir bütün olarak psikolojik personel 
güçlendirme değişkenini yöneticinin güç kaynakları ile tahmin etmek istatistiksel olarak mümkündür. Sonuçlara bakıldığında; -1 ile +1 arasında değișen değerler alan korelasyon katsayısının bu modeldeki oranının $r=.33$ olduğu görülmektedir. Belirlilik katsayısı ise bağımsız değişkenlerin bu modelin \%11'ini açıkladığını göstermektedir $\left(\mathrm{R}^{2}\right.$ $=.11)$. Standardize edilmiş beta değerlerinden hareketle bu ilişkideki bağımsız değişkenlerin bağımlı değişkeni etkileme sırasına bakıldığında tek anlamlı etkinin uzmanlık gücünde olduğu görülmektedir $(\beta=-.24)$. Diğer bağımsız değişkenler, beta değerlerinin anlamsız olması sebebiyle bir etki göstermemiştir $(p>.05)$. Görülmektedir ki; uzmanlık gücü psikolojik personel güçlendirmeyi açıklamada negatif yönlü katkı yapmaktadır.

İkinci regresyon modelinde bağımsız değişkenler olan zorlayıcı güç, yasal güç, ödüllendirme gücü, karizmatik güç ve uzmanlık gücü ile bağımlı değişken olan psikolojik personel güçlendirmenin anlam boyutu arasında yapılan çoklu doğrusal regresyon analizinin sonuçları görülmektedir. F değeri \%ol anlamlılık düzeyinde istatistiksel olarak anlamlıdir $\left[\mathrm{F}_{(5,149)}=5.047, \mathrm{p}<.001\right]$. Yani psikolojik personel güçlendirmenin anlam boyutunu yöneticinin güç kaynakları ile tahmin etmek istatistiksel olarak mümkündür. Sonuçlara bakıldığında; -1 ile +1 arasında değişen değerler alan korelasyon katsayısının bu modeldeki oranının $r=.38$ olduğu görülmektedir. Belirlilik katsayısı ise bağımsız değişkenlerin bu modelin \%14'ünü açıkladığını göstermektedir $\left(\mathrm{R}^{2}=.14\right)$. Standardize edilmiş beta değerlerinden hareketle bu ilişkideki bağımsız değişkenlerin bağımlı değişkeni etkileme sırasına bakıldığında tek anlamlı etkinin yasal güçte olduğu görülmektedir $(\beta=.33)$. Diğer bağımsız değişkenler, beta değerlerinin anlamsız olması sebebiyle bir etki göstermemiştir ( $p>$ .05). Görülmektedir ki; yasal güç psikolojik personel güçlendirmenin anlam boyutunu açıklamada pozitif yönlü katkı yapmaktadır.

Üçüncü regresyon modelinde bağımsız değişkenler olan zorlayıcı güç, yasal güç, ödüllendirme gücü, karizmatik güç ve uzmanlık gücü ile bağımlı değişken olan psikolojik personel güçlendirmenin yetkinlik boyutu arasında yapılan çoklu doğrusal regresyon analizinin sonuçları görülmektedir. $F$ değeri $\% 5$ anlamlılık düzeyinde istatistiksel olarak anlamsızdır $\left[\mathrm{F}_{(5,149)}=1.821, \mathrm{p}>.05\right]$. Yani psikolojik personel güçlendirmenin yetkinlik boyutunu yöneticinin güç kaynakları ile tahmin etmek istatistiksel olarak mümkün değildir.

Dördüncü regresyon modelinde bağımsız değişkenler olan zorlayıcı güç, yasal güç, ödüllendirme gücü, karizmatik güç ve uzmanlık gücü ile bağımlı değişken olan psikolojik personel güçlendirmenin özerklik boyutu arasında yapılan çoklu doğrusal regresyon analizinin sonuçları görülmektedir. F değeri $\% 5$ anlamlılık düzeyinde istatistiksel olarak anlamsızdır $\left[\mathrm{F}_{(5,149)}=1.680, \mathrm{p}>.05\right]$. Yani psikolojik personel güçlendirmenin özerklik boyutunu yöneticinin güç kaynakları ile tahmin etmek istatistiksel olarak mümkün değildir.

Beşinci regresyon modelinde bağımsız değişkenler olan zorlayıcı güç, yasal güç, ödüllendirme gücü, karizmatik güç ve uzmanlık gücü ile bağımlı değişken olan psikolojik personel güçlendirmenin etki boyutu arasında yapılan çoklu doğrusal regresyon analizinin sonuçları görülmektedir. $\mathrm{F}$ değeri $\% 1$ anlamlılık düzeyinde istatistiksel olarak anlamlıdır $\left[\mathrm{F}_{(5,149)}=3.733, \mathrm{p}<.01\right]$. Yani psikolojik personel güçlendirmenin etki boyutunu yöneticinin güç kaynakları ile tahmin etmek istatistiksel olarak mümkündür. Sonuçlara bakıldığında; -1 ile +1 arasında değişen değerler alan 
korelasyon katsayısının bu modeldeki oranının $r=.33$ olduğu görülmektedir. Belirlilik katsayısı ise bağımsız değişkenlerin bu modelin \%11'ini açıkladığını göstermektedir $\left(\mathrm{R}^{2}\right.$ $=.11)$. Standardize edilmiş beta değerlerinden hareketle bu ilişkideki bağımsız değişkenlerin bağımlı değişkeni etkileme sırasına bakıldığında en büyük etki sırasıyla uzmanlık gücü $(\beta=-.28)$ ve karizmatik güçtedir $(\beta=.23)$. Diğer bağımsız değişkenler, beta değerlerinin anlamsız olması sebebiyle bir etki göstermemiştir $(\mathrm{p}>.05)$. Görülmektedir ki; psikolojik personel güçlendirmenin anlam boyutunu açıklamada uzmanlık gücü negatif yönlü katkı yaparken, karizmatik güç pozitif yönlü katkı yapmaktadır.

\section{Sonuç ve Tartışma}

Bu çalışma ile Sosyal Mübadele Teorisi (Blau, 1964) temel alınarak zorlayıcı güç, yasal güç, ödüllendirme gücü, karizmatik güç, uzmanlık gücü ve bilgiye dayalı güç olmak üzere altı farklı türden oluşan yöneticinin güç kaynaklarının bir bütün olarak psikolojik personel güçlendirme algısı üzerindeki ve psikolojik personel güçlendirme algısının boyutları olan anlam, yetkinlik, özerklik ve etki üzerindeki açıklayıcılık (yordayıcılık) durumunu belirlemek amaçlanmıştır. Bu amaç doğrultusunda Osmaniye il merkezindeki özel hastane çalışanları üzerinde uygulamalı bir araştırma gerçekleştirilmiştir. Nicel araştırma deseni ve ilişkisel tarama modeli kapsamında gerçekleştirilen çalışmada kolayda örnekleme yöntemi ve anket tekniği aracılığıyla çalışanlardan veri toplanmıştır. Yöneticinin güç kaynakları ve psikolojik personel güçlendirme arasındaki ilişkileri belirlemek için istatistiksel analiz yazılımları aracılığıyla korelasyon ve regresyon analizinden faydalanılmıştır. Yapılan incelemeler sonucunda açıklayıcı bulgulara ulaşılmıştır.

Katılımcılardan elde edilen verilerde yöneticinin güç kaynaklarının bir türü olan bilgiye dalı güç, istatistiksel analizler için gerekli olan ön koşullara uygunluk göstermemesi sebebiyle araştırma modelinden çıkarılmıştır. Araştırmanın sonuçlarına göre; uzmanlık gücünün çalışanların bir bütün olarak psikolojik personel güçlendirme algısını negatif yönlü olarak açıkladığı sonucuna ulaşılmıştır. Yasal güçle hareket eden yöneticinin psikolojik personel güçlendirmeye ait anlam boyutunu açıklamada pozitif yönde katkı yaptığı tespit edilmiştir. Bununla birlikte, karizmatik güce sahip yöneticinin psikolojik personel güçlendirmeye ait etki boyutunu açıklamada pozitif yönde katk1 yaptığı bulgulanmıştır. Son olarak uzmanlık gücüne sahip olan yöneticinin psikolojik personel güçlendirmeye ait etki boyutunu açıklamada negatif yönde katkı yaptığı sonucuna ulaşılmıştır. Diğer yandan, yöneticinin güç kaynaklarının psikolojik personel güçlendirmenin boyutları olan yetkinlik ve özerklik üzerindeki etkisi istatistiksel olarak anlamsız çıkmıştır.

Yöneticinin güç kaynaklarının psikolojik personel güçlendirme üzerinde etki göstereceği öngörülerek gerçekleştirilen bu araştırmanın sonuçlarının Sosyal Mübadele Teorisi'nin (Blau, 1964) işaret ettiği noktalarla örtüştüğü düşünülmektedir. Çünkü söz konusu teori, genel bir ifadeyle, karşılıklı gerçekleşen ilişkileri ekonomik, sosyolojik ve psikolojik anlamda bir değiş tokuş ilişkisi olarak açıklamakta ve araştırmanın sonuçlarına göre de çalışanların psikolojik personel güçlendirme algıları yöneticilerinin hangi tür güç kaynağıyla tutum ve davranış gerçekleştirdiğine göre değişmektedir.

Yazında bu araştırmanın modelini ve sonuçlarını destekleyen farklı çalışmalar da bulunmaktadır. Öncelikle genel bir bakış açısıyla yorumlamak gerekirse, söz konusu çalışmalar yöneticinin istek ve talimatlarına onun sahip olduğu etkileme gücünün türüne 
yani güç kaynağına göre riayet eden bir anlayışın yaygınlaştığını ileri sürmektedirler (Koçel, 2013). Yani çalışanlar makama dayalı otoriteye yönelik gösterilen itaatten gücün kaynağına bağlı olarak gösterilen uyuma doğru evirilmektedirler. Bu genel yorumun bir destekleyicisi olarak güç olgusunun insan davranışlarının bir belirleyicisi olduğunu, bireylerarası ilişkileri ve iletişimi etkilediğini ve özellikle yöneten ve yönetilen arasındaki ilişkilerde güç olgusuna ayrı bir önem verilmesi gerektiğini ifade eden çalışmalar gösterilebilir (Bayrak, 2001). Yapılan araştırmalara daha detaylı bakmak gerekirse, bir çalışmada yöneticiler tarafından çalışanlara tanınan karar verme serbestlik derecesinin çalışanların liderlik algılamalarına doğrudan etki edeceği ifade edilmiştir (Korkmazyürek ve Hazır, 2017). Bu araştırma modeline benzer bir şekilde yapılan başka bir araştırmada; çalışan odaklı, üretim odaklı ve değişim odaklı olmak üzere üç farklı türden oluşan liderlik tarzlarının psikolojik personel güçlendirme algısı üzerinde farklı etkiler gösterdiği bulgulanmıştır (Çavuş ve Demir, 2010). Benzer bir araştırmada etkileşimci liderlik, dönüşümcü liderlik, karizmatik liderlik, stratejik liderlik ve hizmetkar liderlik türlerinden her birinin örgütsel yapıya farklı yansımaları olduğu tespit edilmiştir (Taşgit ve Sert, 2017). Diğer bir araştırmada ise yıkıcı yönetim tarzının çalışanların farklı izlenim yönetim taktikleri sergilemesine sebep olduğu ortaya konulmuştur (Aksay ve Güğerçin, 2016). Belirtildiği üzere yazındaki tüm bu çalışmalar araştırmanın modelini ve bulgularını destekler niteliktedir.

Araştırmanın sonuçları yöneticilere insanların psikolojik bir varlık olduğu gerçeğini hiçbir zaman ihmal etmemeleri hususunda sorumluluk yüklemektedir. Yöneticilerin çalışanların psikolojik personel güçlendirme algılarına pozitif katkı sağlayabilmek için tutum ve davranışlarında daha çok yasal gücün gerektirdiği niteliklerle hareket etmeleri ve karizmatik lider özelliklerini rol model almaları gerekmektedir. Ayrıca yöneticilerin sahip oldukları uzmanlıkları izleyicilerine aktarırken bilinçli olmaları gerektiği çıkarımı yapılabilir. Asıl fonksiyonu değer katmak olan uzman yöneticiler yanlış tutum ve davranışlarla çalışanları tam tersine değersiz hissettirebileceklerini gözden kaçırmamalıdırlar.

Çalışmada değişkenler arası ilişkiler ilk defa ölçüldüğü için örneklem seçiminde kolayda örnekleme yöntemi kullanılmıştır. Değişkenler arasındaki ilişkilerin var olduğu ispatlandığı için gelecek dönem araştırmalarında farklı örnekleme yöntemleri (amaçlı örnekleme, kota örnekleme gibi) kullanılarak daha tutarlı sonuçlara ulaşılabilir. Diğer yandan, örnekleme sürecinde ideal örneklem büyüklüğü hesaplanarak araştırma sonuçlarının evrene genellenebilmesi sağlanabilir. Araştırma modelinin daha kapsamlı hale getirilmesi adına yöneticilik/liderlik ve personel güçlendirme ilişkisine etki potansiyeli yüksek konular olan; lider üye etkileşimi, öz yeterlilik, iş tatmini, örgüt kültürü, kişilik özellikleri, kişi-iş uyumu veya kişi örgüt uyumu konuları ara değişkenler olarak modele eklenebilir. Örneğin, Lider Üye Etkilemişi Teorisi’ne göre liderlerin bazı izleyici gruplarına iltimas geçtiği öne sürülmektedir (Yalçın, 2015). Dolayısıyla, güç kaynakları ve personel güçlendirme ilişkisinde lider üye etkileşiminin rolü amaçlı örnekleme yöntemi kullanılarak yapılacak bir araştırmayla incelenerek söz konusu ilişkilerdeki örtülü noktalara netlik kazandırılabilir. Ayrıca bu araştırma modeli nitel (kalitatif) araştırma desenleri üzerinden gerçekleştirilerek psikolojik personel güçlendirme ve yöneticinin güç kaynakları ilişkisine daha derinlemesine bir bakış açısı sağlanabilir. 
Son not: Bu çalışma, 25-27 Mayıs 2017 tarihlerinde Ankara'da düzenlenen "25. Ulusal Yönetim ve Organizasyon Kongresi”nde sunulan bildiri çalışmasının gözden geçirilerek genişletilmiş halidir.

\section{Kaynakça}

Aksay, B. ve Güğerçin, U. 2016. Yıkıcı yönetimin izlenim yönetimi taktikleri üzerindeki etkisi: Beyaz yakalı çalışanlar üzerine bir araştırma. Ç. Ü. Sosyal Bilimler Enstitüsü Dergisi 25(3), 441-456.

Ashforth, B. E. (1989). The experience of powerlessness in organizations. Organizational Behavior and Human Decision Processes 43(2), 207-242.

Ateş, F. (2017). 3. bölüm. Ö. Turunç \& H. Turgut (Ed.), Yönetim ve strateji: 101 teori ve yaklaşım içinde (s. 125-159). Ankara: Siyasal Kitabevi.

Barbuto, J. E. ve Hayden, R. W. (2011). Testing relationships between servant leadership dimensions and leader member exchange (LMX). Journal of Leadership Education 10(2), 22-37.

Bayrak, S. (2001). Yönetimde bir ihmal konusu olarak güç ve güç yönetimiII. Süleyman Demirel Üniversitesi Iktisadi ve İdari Bilimler Fakültesi Dergisi 6(1), 23-42.

Blau, P. M. (1964), Exchange and power in social life, New York, NY: John Wiley \& Sons.

Bowling A. (2002). Research methods in health. In Investigating Health and Health Services. Buckingham: Open University Press. ISBN: 0335206433

Brief, A. P. ve Nord, W. R. (1990). The meaning of occupational work: A collection of essays. Lexington: Lexington Books

Conger, J. A. ve Kanungo, R. N. (1988). The empowerment process: Integrating theory and practice. Academy of Management Review 13(3), 471-482.

Conger, J. A. 1989. Leadership: The art of empowering others. The Academy of Management Executive 3(1), 17-24.

Cronbach, L. J. (1951). Coefficient alpha and the internal structure of tests. Psychometrika 16(3), 297-334.

Cropanzano, R. ve Mitchell, M. S. (2005). Social exchange theory: An interdisciplinary review. Journal of Management 31(6), 874-900.

Çavuş, M. F. ve Akgemci, T. (2008). İşletmelerde personel güçlendirmenin örgütsel yaratıcılık ve yenilikçiliğe etkisi: İmalat sanayiinde bir araştırma. Selçuk Üniversitesi Sosyal Bilimler Enstitüsü Dergisi 20, 229-244.

Çavuş, M. F. ve Demir, Y. (2010). Liderlik tarzının personel güçlendirme üzerine etkileri. Üçüncü Sektör Kooperatifçilik 45, (2) : 1-14

Deci, E. L., Connell, J. P. ve Ryan, R. M. (1989). Self-determination in a work organization. Journal Of Applied Psychology 74(4), 580.

Durbin, J. ve Watson, G. S. (1971). Testing for serial correlation in least squares regression. III. Biometrika 58(1), 1-19.

Gioia, D. A. ve Sims Jr, H. P. (1983). Perceptions of managerial power as a consequence of managerial behavior and reputation. Journal of Management 9(1), 7-24. 
Gist, M. E. ve Mitchell, T. R. (1992). Self-efficacy: A theoretical analysis of its determinants and malleability. Academy Of Management Review 17(2), 183-211.

İhtiyaroğlu, N. (2017). Yapısal ve psikolojik güçlendirmenin öğretmen motivasyonu üzerindeki etkisi. Kırıkkale Üniversitesi Sosyal Bilimler Dergisi 7(2), 361-377.

Kanbur, E. (2018). Havacılık sektöründe psikolojik güçlendirme, iş performansı ve işten ayrılma niyeti arasındaki ilişkilerin incelenmesi. Uluslararası Yönetim İktisat ve Işletme Dergisi 14(1), 147-162.

Karagonlar, G., Öztürk, E. B. ve Özmen, Ö. N. (2015). Çalışanın örgütle sosyal mübadele algısı ve işten ayrılma niyeti: İşe cezbolmanın ve öz yeterliliğin rolü. METU Studies in Development 42(3), 411.

Karagöz, Y. (2016). SPSS 23 ve AMOS 23 uygulamalı istatistiksel analizler. Ankara: Nobel Akademik Yayıncılık. ISBN: 978-605-320-547-0

Kızanlıklı, M. M., Koç, H. ve Kılıçlar, A. (2016). Örgütsel Güç ve Gücün Kaynakları Üzerine Kavramsal Bir İnceleme. İşletme Araştırmaları Dergisi 8(4), 488-504.

Kline, R. B., (2011). Principles and practice of structural equation modelling. 3rd Edition, New York: Guilford Press.

Koçel, T. (2013). İşletme yöneticiliği. İstanbul: Beta. ISBN: 978-605-377-573-3

Korkmazyürek ve Hazır (2017). Algl, tutum ve duygular. Ü. Sığrı \& S. Gürbüz (Ed.), Örgütsel davranış içinde (s. 46-80). İstanbul: Beta. ISBN: 978-605-333-841-3

Mahalanobis, P. C. (1936). On the generalized distance in statistics. Proceedings of the National Institute of Sciences (Calcutta), 2, 49-55.

McClelland, D. C. ve Burnham, D. H. (2003). Power is the great motivator. Harvard Business Review 81(1), 117-126.

Meydan, C. H. (2010). Örgüt kültürü, örgütsel güç ve örgütsel adalet algılarının bireyin iş tatmini ve örgüte bağlılı̆̆ üzerine etkisi: Kamuda bir araştırma. (Yayımlanmamış Doktora Tezi), KHO Savunma Bilimleri Enstitüsü, Ankara.

Miguel, M. C., Ornelas, J. H. ve Maroco, J. P. (2015). Defining psychological empowerment construct: Analysis of three empowerment scales. Journal of Community Psychology 43(7), 900-919.

Nunnally, J. C. (1978). Psychometric theory. New York, London: McGraw-Hill

O'Brien, R. M. (2007). A caution regarding rules of thumb for variance inflation factors. Quality \& Quantity 41(5), 673-690.

Podsakoff, P. M. ve Organ, D. W. (1986). Self-reports in organizational research: Problems and prospects. Journal of Management 12(4), 531-544.

Podsakoff, P. M., MacKenzie, S. B., Lee, J. Y. ve Podsakoff, N. P. (2003). Common method biases in behavioral research: A critical review of the literature and recommended remedies. Journal of Applied Psychology 88(5), 879.

Polatcı, S. ve Özçalık, F. (2013). Yapısal ve psikolojik güçlendirmenin işyeri nezaketsizliği ve tükenmişliğe etkisi. İşletme Bilimi Dergisi 1(1), 17-34.

Prilleltensky, I. (2008). The role of power in wellness, oppression and liberation: The promise of psychopolitical validity. Journal of Community Psychology 36(2), 116-136. 
Rahim, M. A., Kim, N. H. ve Kim, J. S. (1994). Bases of leader power, subordinate compliance, and satisfaction with supervision: A cross-cultural study of managers in the US and S. Korea. The International Journal of Organizational Analysis 2(2), 136-154.

Rahim, M. A. (2004). Leader power, followers' conflict management strategies, and propensity to leave a job: A cross-cultural study. International Association for Conflict Management, June, Pittsburgh, PA.

Raven, B. H., Schwarzwald, J. ve Koslowsky, M. (1998). Conceptualizing and measuring a power/interaction model of interpersonal influence. Journal of Applied Social Psychology 28(4), 307-332.

Raven, B. H. (2008). The bases of power and the power/interaction model of interpersonal influence. Analyses of Social Issues and Public Policy 8(1), 1-22.

Rhoades, L., Eisenberger, R. ve Armeli, S. (2001). Affective commitment to the organization: The contribution of perceived organizational support. Journal of Applied Psychology 86(5), 825-836.

Shetty, Y. K. (1978). Managerial power and organizational effectiveness: A contingency analysis. Journal of Management Studies 15(2), 176-186.

Spreitzer, G. M. (1995). Psychological empowerment in the workplace: Dimensions, measurement, and validation. Academy of Management Journal 38(5), 1442-1465.

Sürgevil, O., Tolay, E. ve Topoyan, M. (2013). Yapısal güçlendirme ve psikolojik güçlendirme ölçeklerinin geçerlilik ve güvenilirlik analizleri. Journal of Yaşar University 8(31), 5371-5391.

Taşgit, Y. E. ve Sert, H. T. (2017). Liderlik tarzlarının örgütsel yapıya yansımaları üzerine bir araştırma. Işsletme Araştırmaları Dergisi 9(4), 530-550

Taşlıyan, M., Harbalığlu, M. ve Hırlak, B. (2015). Personel güçlendirmenin örgütsel bağl11ık ve örgütsel vatandaşlık davranışına etkisi: akademisyenler üzerine bir araştırma. Çankırı Karatekin Üniversitesi Sosyal Bilimler Enstitüsü Dergisi 6(1), 313-334.

Thomas, K. W. ve Velthouse, B. A. (1990). Cognitive elements of empowerment: An "interpretive" model of intrinsic task motivation. Academy of Management Review 15(4), 666-681.

Tolay, E., Sürgevil, O. ve Topoyan, M. (2012). Akademik çalışma ortamında yapısal ve psikolojik güçlendirmenin duygusal bağlılık ve iş doyumu üzerindeki etkileri. Ege Academic Review 12(4), 449-465.

Yalçın, A., (2015). Liderlik. İ. Erdem (Ed.), Örgütsel davranış içinde (s. 376-416). İstanbul: Nobel. ISBN: 978-605-133-142-3

Y1ld1z, B. ve Y1ldiz, H. (2015). The effect of servant leadership on psychological ownership: The moderator role of perceived organizational support. Journal of Global Strategic Management 9(2), 65-77.

Yıldız, B. (2016). Hizmetkâr liderlik algısının lider-üye etkileşimi üzerindeki etkisi: Kamu sektörü çalışanları üzerine bir araştırma. KAÜIIIBFD 7(14), 499-517.

Zimmerman, M. A. (1995). Psychological empowerment: Issues and illustrations. American Journal of Community Psychology 23(5), 581-598. 


\title{
Explaining the Psychological Empowerment through Managers' Sources of Power: A Research in Health Sector
}

\author{
Alptekin DEVELI \\ Tokat Gaziosmanpaşa University \\ Reşadiye Vocational School \\ Tokat, Turkey \\ orcid.org/0000-0001-7232-5603 \\ alptekin.develi@gop.edu.tr
}

\author{
Mustafa Fedai ÇAVUŞ \\ Osmaniye Korkut Ata University \\ Faculty of Economics and Administrative \\ Sciences, Osmaniye, Turkey \\ orcid.org/0000-0002-2515-5805 \\ mfcavus@,osmaniye.edu.tr
}

\author{
Bülent ÖZ \\ Osmaniye Korkut Ata University \\ Faculty of Economics and Administrative Sciences \\ Osmaniye, Turkey \\ orcid.org/0000-0001-8756-5386 \\ bulentoz@osmaniye.edu.tr
}

\section{Extensive Summary}

\section{Introduction}

It is generally accepted situation in the literature of organizational behavior in which the most valuable element in business life is the employees. Therefore, each issue related to employees is important. In this sense, employees' perceptions related to psychological empowerment which means that employees perceive themselves as an efficient individual (Conger and Canungo, 1988) is of great importance in business life.

Determining the antecedents of psychological empowerment is a situation that is tried to be investigated by both the researchers and managers. For this reason, the managers' sources of power, which is the other variable of the research, have been discussed in this context. So, the top authority in an organization is the managers. A relation between the managers and employees occurs in the form of an interdependence relationship. Hence, employees' perceptions regarding to their managers will vary depending on managers' sources of power. Based on these considerations, it was envisaged that the power sources used by the managers would be a possible determinant of psychological empowerment.

The relationship among the research variables can be explained theoretically through the Social Exchange Theory (Blau, 1964). When considering the place of the Social Exchange Theory in business life, it can be said that this theory explains the relationships between the employers and employees (Cropanzano and Mitchell, 2005; Ates, 2017; Yildiz and Yildiz, 2015). Accordingly, when the employer shows positive attitudes and behaviors towards employees, employees will also show positive attitudes and behaviors towards their employers and their organizations (Rhoades et al., 2001). Similarly, the employee who is exposed to negative attitudes and behaviors by his employer will be in the same way as to the respond. In this context, it is thought that the theory is a powerful theory that explains the relationships between psychological empowerment and managers' sources of power. 
Based on both the Social Exchange Theory (Blau, 1964) and the related literature, the research question of this study is: "whether the manager's sources of power are the predictors of psychological empowerment or not."

\section{Data and Method}

In order to determine the predictor status of the managers' sources of power on the perception of psychological empowerment, a practical research was conducted on employees working at private hospitals in the city center of Osmaniye, Turkey.

In the study conducted within the context of the quantitative research pattern and correlational research design, data were collected from 169 people via convenience sampling method and survey technique. Firstly, the obtained data were prepared for the analysis. Based on the results of the missing value analysis, 14 questionnaires were excluded from the observation due to the incomplete answer error. In the outlier analysis by using the Mahalanobis Distance Method, it was found that there is no outlier value in the data set because, there is no data which is remote from the center of the subjects at the statistical significance level of 1\% (Mahalanobis, 1936). After removing the problematic questionnaire forms, the final sample count in the data set is $155(\mathrm{n}=$ 155). According to the results of the skewness-kurtosis test, the biggest skewness value: -2.23 and the biggest kurtosis value: 6.69. Since the skewness values are within \pm 3 and the kurtosis values are within \pm 10 threshold values, it is concluded that the data shows normal distribution (Kline, 2011). For this reason, parametric analyses were used in this study.

The Harman' single factor test was used to control the probable common method variance problem in the data set. In this direction, a total of 45 items of 10 variables used in the questionnaire were analyzed by the factor analysis with no rotation. According to the findings, the items were not collected in one dimension and showed a multidimensional structure consisting of 10 sub-dimensions. In addition, in order to obtain a single and general factor, when the factor number was fixed to 1 in the explanatory factor analysis, it was found that the only factor that emerged was explaining a low portion corresponding to $24 \%$ of the total variance, not the majority. According to these results, it was found that there is no common method variance problem in the obtained data (Podsakoff ve Organ, 1986; Podsakoff et al., 2003).

To measure the managers' sources of power the scale developed by Raven et al. (1998) and made Turkish validation by Meydan (2010) was used. The scale consists of 33 items and 6 dimensions. Dimensions of the scale are; coercive power (6 items), legitimate power (12 items), reward power (6 items), referent power (3 items), expert power (3 items) and informational power (3 items). Besides, The Psychological Empowerment Scale developed by Spreitzer (1995) and made Turkish validation by Sürgevil et al. (2013) was used. The scale consists of 12 items and 4 dimensions which are meaning, competence, self-determination and impact. Each dimension consists of 3 items.

\section{Findings}

In order to determine the internal consistency of the measures used in the study, reliability analysis was performed with the Cronbach's Alpha $(\alpha)$ method (Cronbach, 1951). According to the results of the reliability analysis, the alpha coefficients are as follows: managers' power sources as a whole $(\alpha=.92)$ and coercive power $(\alpha=.76)$, 
legitimate power $(\alpha=.79)$, reward power $(\alpha=.75)$, referent power $(\alpha=.62)$, expert power $(\alpha=.73)$, informational power $(\alpha=.31)$. On the other side, psychological empowerment as a whole $(\alpha=.88)$ and meaning $(\alpha=.78)$, competence $(\alpha=.80)$, selfdetermination $(\alpha=.85)$, impact $(\alpha=.78)$. Since the level of reliability of the informational power was significantly low, only this dimension was excluded from the research model. The Cronbach's Alpha values of all other variables indicate that the internal consistency of the scales exists in a reliable level (Nunnaly, 1978; Bowling, 2002; Nakip, 2013).

The results of the multiple linear regression analysis suggest that the managers acting with expert power negatively contributed to the explanation of psychological empowerment as a whole $\left[\mathrm{F}_{(5,149)}=3.713, \mathrm{p}<.01, \mathrm{r}=.33, \mathrm{R}^{2}=.11, \beta=-.24\right]$. The managers acting with legitimate power positively contributed to the explanation of the meaning the dimension of psychological empowerment $\left[\mathrm{F}_{(5,149)}=5.047, \mathrm{p}<.001, \mathrm{r}=\right.$ $\left..38, \mathrm{R}^{2}=.14, \beta=.33\right]$. The managers who have referent power positively contributed to the explanation of the impact the dimension of psychological empowerment $\left[\mathrm{F}_{(5,149)}=\right.$ $\left.3.733, \mathrm{p}<.01, \mathrm{r}=.33, \mathrm{R}^{2}=.11, \beta=.23\right]$ and the managers acting with expert power negatively contributed to the explanation of the impact the dimension of psychological empowerment $\left[\mathrm{F}_{(5,149)}=3.733, \mathrm{p}<.01, \mathrm{r}=.33, \mathrm{R}^{2}=.11, \beta=-.28\right]$.

\section{Conclusion}

According to the results of the study; it is concluded that the expert power explains negatively the perception of psychological empowerment as a whole. It has been determined that the manager who acts with legitimate power positively contributes on explaining the meaning dimension of psychological empowerment. Besides, it was found that the manager who has referent power positively contributes on explaining the impact the dimension of psychological empowerment. Finally, it has been concluded that the manager who has the expert power makes a negative contribution to explaining the impact the dimension of psychological empowerment. On the other hand, the effects of the manager's sources of power on the competence and self-determination which are the dimensions of the psychological empowerment were statistically insignificant.

It is thought that the obtained results coincide with the Social Exchange Theory which is the theoretical basis of the study. This theory explains the human relations as mutual exchange relations in terms of economic, sociological and psychological perspective (Blau, 1964). As a matter of fact, according to the results of the study, the psychological empowerment perceptions of the employees vary depending on the managers' sources of power.

In the study, the convenience sampling method was used because the relationships among the variables were measured for the first time. Different sampling methods (such as purposive sampling, quota sampling) can be used in future research. On the other hand, it is possible to generalize the research results to the universe by calculating the ideal sample size during the sampling process. In order to make the research model more comprehensive, some subjects can be added as mediator/moderator variables. For example; leading-member exchange, self-efficacy, job satisfaction, organizational culture, personality traits, person-organization fit or person-job fit. In addition, this research model can be carried out through the qualitative research designs to provide a deeper insight into the relationship between the psychological empowerment and the manager's sources of power. 